\title{
EVALUATION OF PARTNERSHIP RELATIONSHIP IN ORGANIC VEGETABLE SUPPLY CHAIN IN CV. KURNIA KITRI AYU FARM MALANG
}

\author{
Nur Ocvanny Amir ${ }^{*}$, Jabal Tarik Ibrahim, Gumoyo Mumpuni Ningsih, Zubdatul \\ Asror
}

Agribusiness Department, University of Muhammadiyah Malang, Indonesia

*corresponding author: vanny@umm.ac.id

\begin{abstract}
Market demand for organic vegetables at CV. Kurnia Kitri Ayu Farm continues to grow according to consumer needs. Market development is determined by the quality and continuity of the marketing distribution. To maintain this, in its business activities CV. Kurnia Kitri Ayu Farm established partnerships with several parties. The objectives of the research were 1) Knowing the supply chain of organic vegetables both in partnership and non-partnership with CV. KKAF, 2) Knowing the partnership patterns formed in the CV. KKAF, 3) Evaluating trust, commitment, communication, satisfaction, and dependence in organic vegetable supply chain partnerships. Respondents in this study consisted of the head of partner farmer groups, owners of CV. Kurnia Kitri Ayu Farm and the head of staff as a permanent partner for the home industry (baby care). The results showed 1) The flow of the organic vegetable supply chain consisted of the flow of goods, the flow of money, and the flow of information, 2) the partnership patterns contained in the organic vegetable supply chain, namely the plasma core partnership pattern, subcontracts, and general trading, 3) All parties in the supply chain on average feel very confident, have a very good commitment, communicate frequently, feel satisfied, and are very dependent on the performance of its partner members.
\end{abstract}

Keywords: Organic Vegetables, Partnerships, Supply Chain

http://dx.doi.org/10.21776/ub.agrise.2020.020.4.8

Received 11 September 2020

Accepted 20 October 2020

Available online 30 October 2020

\section{INTRODUCTION}

The use of hazardous materials in agricultural production activities has now changed the mindset of society about agricultural products. The public is increasingly aware that the use of chemicals in agricultural productivity, such as synthetic fertilizers, pesticides, and so on, will have side effects for health. Such conditions have made some people switch to implementing organic agricultural activities. According to Mayrowani (2012), a healthy lifestyle has become a new trend and has been institutionalized internationally which requires assurance that agricultural products must have food safety attributes, high nutritional attributes, and ecolabeling attributes. This trend of healthy living is certainly an opportunity for organic farming actors so that currently many organic farming players have emerged along with the increasingly open market share.

Organic farming systems have become a trend in vegetable production. According to Muljaningsih (2011), vegetables are one of the most preferred organic agricultural products for consumers. Some of the organic vegetable producers have been accredited as organic vegetable gardens Poerwanto \& Susila (2014). Based on Indonesian Organic Agriculture Statistics Data (2016), the total area of certified organic land in 2015 is 9,435 $\mathrm{Ha}, 18 \mathrm{Ha}$ in the certified process, and 7,631 $\mathrm{Ha}$ of noncertification. This shows that certified producers are much larger than non-certified producers. This data proves that many organic vegetable product producers have paid attention to their organic farming systems. 
CV. Kunia Kitri Ayu Farm (CV. KKAF) is one of the organic farming business actors in Malang City which has been established for a long time since 2006. This business has an organic certificate as an organic vegetable garden with REG certificate number LSPO - 003 - IDN with SNI 01 - 6729 2002. Until now the market demand for organic vegetables in the CV. KKAF continues to develop according to consumer needs. Market development is determined by the quality and continuity of the marketing distribution. To maintain this, in its business activities CV. KKAF has established partnerships with several parties.

This partnership is a form of the business strategy carried out by CV. KKAF. In cultivation activities, this company partners with several Women's Farmer Groups (KWT) which are members of Mutiara Farm. The partnership formed in cultivation activities is expected to be a forum for transferring cultivation management techniques, scheduling of planting activities, and quality control according to $\mathrm{CV}$ management. KKAF, so that the products produced by KWT according to $\mathrm{CV}$. Meanwhile, in marketing activities, the company partners with a baby porridge company (Baby Care). Partnership in marketing aims to provide market certainty at a mutually agreed price.

This partnership has existed for several years, but in its implementation, there are still several problems, including in meeting consumer demand targets, companies are faced with a situation where the number of vegetable products with the number of requests is sometimes unbalanced, the continuity of delivery is sometimes not on time, and there is a miss communication between supply chain institutions. Therefore, it is important to research Partnership Evaluation in Organic Vegetable Supply Chains at CV. Kurnia Kitri Ayu Farm Malang with the hope of helping problems in maintaining a harmonious partnership relationship.

Research on partnerships in agribusiness has been done a lot, Larasati and Sursura (2020), examine the partnership pattern between Taman Ayu Agro-tourism and Luwak coffee farmers. The partnership pattern that is formed is subcontracting, things that are agreed upon in the form of price, volume, delivery time, and the rights and obligations between Taman Ayu Agriwisata and civet farmers. This study also analyzed the effectiveness of the cooperation contract and the difference in income between a partnership and non-partnership civet farmers. Erfit (2012), examines the analysis of equality in partnerships in horticultural agribusiness. The results showed that the relationship between farmers and collectors was relatively equal, while in contract farming with companies there was relatively no equality. Yulianjaya and Hidayat (2016), research on partnership patterns of chili farmers with skippers outside the village. The partnership pattern that is formed is the agribusiness operational cooperation pattern. From several previous studies, many have examined the agribusiness partnership pattern, but there are still differences where in this study there is an evaluation analysis of trust, commitment, communication, satisfaction, and dependence on organic vegetable supply chain partnerships.

The objectives of this study were 1) Knowing the supply chain of organic vegetables both in partnership and non-partnership with CV. KKAF, 2) Knowing the partnership patterns formed in the CV. KKAF, 3) Evaluating trust, commitment, communication, satisfaction, and dependence in the organic vegetable supply chain partnership between the women farmer groups and CV. Kurnia Kitri Ayu Farm and between CV. Kurnia Kitri Ayu Farm with Baby Care partners.

\section{RESEARCH METHODS}

This research was conducted at CV. Kurnia Kitri Ayu Farm which is located on Jl. Rajawali No. 10 Sukun District, Malang Regency, East Java. The location of this research was chosen purposively, with the consideration of CV. Kurnia Kitri Ayu Farm is one of the businesses that cultivate vegetables with an organic farming system and forms partnerships with several parties. This research was conducted in January-March 2020.

The initial respondent in this study was the owner of CV. Kurnia Kitri Ayu Farm uses a positive sampling method with the consideration that the respondent is a key informant, while other respondents are obtained from the initial respondent's information. The sampling procedure was carried out by using the "snowball sampling" method following the flow of commodities from farmers to consumers to see the conditions of the supply chain of organic vegetables. Then to analyze the partnership relationship of the selected respondents, among others, the head of the partner farmer group, the owner of CV. Kurnia Kitri Ayu Farm and the head of staff as a permanent partner for the home industry (baby care).

Data collection methods in this study include interviews using a structured questionnaire, documentation, and literature studies.

Information and data were then analyzed descriptively qualitatively and quantitatively. The qualitative descriptive method is used to describe the information on the flow conditions of the organic vegetable supply chain and the partnership pattern, while the quantitative descriptive method is used to measure the long-term relationship of the partnership. Long-term relationships using five variables such as trust, commitment, communication, satisfaction, and dependence were 
analyzed using a Likert scale to determine the CV assessment. Kurnia Kitri Ayu Farm towards suppliers and vice versa. The following analysis is used:

\section{Likert Scale}

The measurement of trust, commitment, communication, satisfaction, and dependency variables as long-term relationships is measured using a Likert scale. The analysis was carried out based on the percentage of the scale results where each item was given the same number and type of answers but different answer weights. The Likert scale used in this study is:

a. Strongly Agree (SS) is given a score of 5

b. Agree (ST) is given a score of 4

c. Doubt $(\mathrm{RG})$ was given a score of 3

d. Disagree (TS) is given a score of 2

e. Strongly Disagree (STS) score 1

The steps taken in using the Likert scale are:

a. Determine the number of classes

The classes defined in this study are 5. The first category starts from number 1 where the assessment of trust, commitment, satisfaction, communication, and dependence is the worst up to number 5 where the assessment of trust, commitment, satisfaction, communication, and dependence is the best.

b. Specifies a range

The range is the difference between the highest observed value and the lowest observed value. The range determination formula is as follows:

$$
\mathbf{R}=\mathbf{X t}-\mathbf{X r}
$$

Information:

$\mathrm{R}$ = Range

$\mathrm{Xt}=$ The highest observed value

$\mathrm{Xr}=$ The lowest observed value

The determination of the class interval is formulated as follows:

Information:

$$
\mathbf{I}=\mathbf{R} / \mathbf{K}
$$

I = Class deviation

$\mathrm{R}$ = Range

$\mathrm{K}=$ The highest observed value

\begin{tabular}{|c|c|c|c|c|}
\hline Variable & Range (K) & Class deviation (I) & \multicolumn{2}{|c|}{ Scale } \\
\hline \multirow[t]{5}{*}{ Trust } & $\mathrm{R}=\mathrm{Xt}-\mathrm{Xr}$ & $\mathrm{I}=\mathrm{R} / \mathrm{K}$ & Strongly believe & $: 21,04-25,00$ \\
\hline & $=(5 \times 5)-(5 \times 1)$ & $=20 / 5$ & Believe & $: 17,03-21,03$ \\
\hline & $=20$ & $=4$ & Neutral & $: 13,02-17,02$ \\
\hline & & & Disbelieve & $: 9,01-13,01$ \\
\hline & & & Strongly disbelieve & $: 5,00-9,00$ \\
\hline \multirow[t]{5}{*}{ Commitment } & $\mathrm{R}=\mathrm{Xt}-\mathrm{Xr}$ & $\mathrm{I}=\mathrm{R} / \mathrm{K}$ & Very good & $: 16,84-20,00$ \\
\hline & $=(4 \times 5)-(4 \times 1)$ & $=16 / 5$ & Good & $: 13,63-16,83$ \\
\hline & $=16$ & $=3,2$ & Neutral & $: 10,42-13,62$ \\
\hline & & & Poor & $: 7,21-10,41$ \\
\hline & & & Very poor & $: 4,00-7,20$ \\
\hline \multirow[t]{5}{*}{ Communication } & $\mathrm{R}=\mathrm{Xt}-\mathrm{Xr}$ & $\mathrm{I}=\mathrm{R} / \mathrm{K}$ & Very often & $: 16,84-20,00$ \\
\hline & $=(4 \times 5)-(4 \times 1)$ & $=16 / 5$ & Often & $: 13,63-16,83$ \\
\hline & $=16$ & $=3,2$ & Neutral & $: 10,42-13,62$ \\
\hline & & & Seldom & $: 7,21-10,41$ \\
\hline & & & Very seldom & $: 4,00-7,20$ \\
\hline \multirow[t]{4}{*}{ Satisfaction } & $\mathrm{R}=\mathrm{Xt}-\mathrm{Xr}$ & $\mathrm{I}=\mathrm{R} / \mathrm{K}$ & Very satisfied & : 21,04 -25,00 \\
\hline & $=(5 \times 5)-(5 \times 1)$ & $=20 / 5$ & Satisfied & $: 17,03-21,03$ \\
\hline & $=20$ & $=4$ & Neutral & $: 13,02-17,02$ \\
\hline & & & $\begin{array}{l}\text { Unsatisfied } \\
\text { Very unsatisfied }\end{array}$ & $\begin{array}{l}: 9,01-13,01 \\
.5,00-9,00\end{array}$ \\
\hline \multirow[t]{5}{*}{ Dependence } & $\mathrm{R}=\mathrm{Xt}-\mathrm{Xr}$ & $\mathrm{I}=\mathrm{R} / \mathrm{K}$ & Strongly depend & : 16,84 -20,00 \\
\hline & $=(4 \times 5)-(4 \times 1)$ & $=16 / 5$ & Depend & $: 13,63-16,83$ \\
\hline & $=16$ & $=3,2$ & Neutral & $: 10,42-13,62$ \\
\hline & & & Not depend & $: 7,21-10,41$ \\
\hline & & & Strongly not depend & $: 4,00-7,20$ \\
\hline
\end{tabular}

Table 1. Measurement Results of Each Variable Based on a Likert Scale 
2. Descriptive Analysis of Percentage

Percentage descriptive analysis was used to describe the data in this study according to categories consisting of, trust, commitment, communication, satisfaction, and dependence. The steps taken in using percentage descriptive analysis techniques are (Nugroho, 2005):

a. Create a questionnaire answer distribution table

b. Determine the score of the respondent's answer with the provisions of the predetermined score. c. Add up the answer scores obtained from each respondent.

d. Enter these scores into the formula

$$
D P=\frac{n}{N} \times 100 \%
$$

Information:

DP: Descriptive Percentage (\%)

$\mathrm{n}$ : The number of values obtained

$\mathrm{N}$ : The number of ideal scores

\section{RESULTS AND DISCUSSION}

\section{The flow of Organic Vegetable Supply Chain at CV. Kurnia Kitri Ayu Farm}

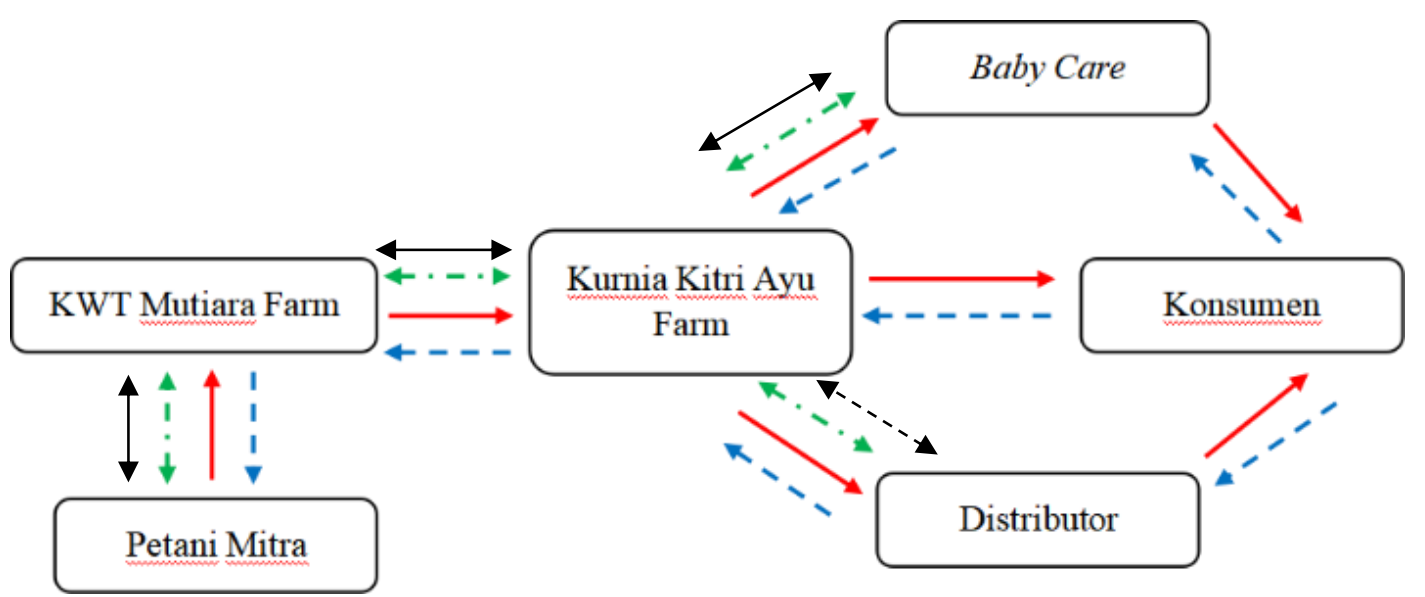

Information:

$\begin{array}{ll}\longrightarrow & \text { Product Flow } \\ & \text { Information Flow } \\ & \text { Money Flow } \\ & \text { Partnership } \\ & \text { A Non-Permanent Partnership }\end{array}$

Figure 1. Organic Vegetable Supply Chain Structure

Based on Figure 1, it can be seen that there is a product flow, information flow, and money flow in the organic vegetable supply chain. Here's an explanation of each:

\section{Product flow}

The flow of organic vegetables starts with partner farmers as producers and initial suppliers of vegetables who are members of the Mutiara Farm Women Farmers Group (KWT). KWT Mutiara Farm covers $3 \mathrm{KWT}$, all of which are KWT members who are organic vegetable producers with a total of 30 farmers. The yields of all these farmers are then deposited into KWT Mutiara Farm. Then
Mutiara Farm sent some of its vegetables to CV. Kurnia Kitri Ayu Farm. Kurnia Kitri Ayu Farm is an actor or member of the supply chain structure

whose role is quite important. The main activity carried out by Kurnia Kitri Ayu Farm is distributing and marketing organic vegetables obtained from suppliers. The activities before the marketing process are first to do sorting and grading because the vegetables obtained from KWT have not yet undergone the sorting and grading stages. Sorting activity is an activity of separating and selecting vegetables that are not suitable for sale. Vegetables are selected and categorized based on the suitability 
of quality and quality. Organic vegetables that are in the proper category will enter the washing and packaging stage and then distributed to baby care company partners and supermarket distributors, partners. The amount of vegetables sent is by Kurnia Kitri Ayu Farm's ability to provide or market. The partner company takes the vegetables themselves by using a boxcar, while the vegetables sent by the expedition are for supermarket distributor partners who do not collect the vegetables directly on the spot. Apart from distributing the vegetables to partner baby care companies and supermarket distributors, CV. KKAF also sells directly to consumers without forming a partnership.

2. Information flow

The flow of information that occurs in the organic vegetable supply chain has shown that the flow of information between partner institutions is 2-way, while there is no communication with the end consumer because these consumers are diverse, who usually come directly to buy the products they need. The communication that is formed between partner institutions includes information on market prices, the amount of vegetable supply available, to the status of product collection and delivery.

3. Money flow

The direction of this money flow is reversed with the direction of product flow. The flow of money occurs when a transaction occurs between the seller and the buyer, where the buyer processes the payment for organic vegetables purchased from the supplier or seller. This payment process is carried out in cash (cash) or transfer. Transaction activities in supply chain partnerships are carried out when vegetable products are collected or purchased according to an agreed schedule. Whereas in nonpartnership supply chains there is no payment schedule, so payment is made directly when buying products with the same system, namely in cash.

\section{Partnership Pattern in Organic Vegetable Supply Chain}

1. The partnership between Farmers and Mutiara Farm and CV. Kurnia Kitri Ayu Farm

The partner farmers in this study are members of KWT Melati Wangi, KWT Anggrek, and KWT Melati which are shaded by KWT Mutiara Farm. The core manager of KWT Mutiara Farm is also part of partner farmers. The formation of KWT Mutiara Farm is based on making it easier to uniform the activities of each KWT. Furthermore, KWT Mutiara Farm is also covered by CV. Kurnia Kitri Ayu Farm, thus forming a partnership pattern, namely the plasma core pattern. Where, the core of this partnership, namely $\mathrm{CV}$. KKAF and those who became plasma were KWT Mutiara Farm which housed 3 other KWT.

As a core company, CV. KKAF provides knowledge transfer, cultivation techniques, cultivation management techniques, and provides direction on the quality and quantity of vegetables as requested by $\mathrm{CV}$. KKAF to KWT Mutiara Farm which is then transferred back by KWT Mutiara Farm to member partner farmers. Farmers are given directions, assignments, and a schedule for each of the crops that must be cultivated on their land according to the farmer's ability. This direction is given directly by the KWT administrator who shelters the farmers. Farmers' activities range from land management, seeding, and nursery, fertilization, planting, maintenance, harvesting to post-harvest processing. Leafy vegetables are harvested when the harvest age ranges from 20-25 days. The demand for organic vegetables is routine every week, so after harvest, the farmers are required to replant immediately. It is endeavored to replant with the same type of vegetable, this is feared to damage soil fertility. The harvest from this plasma company must then be distributed to $\mathrm{CV}$. KKAF according to the request of $\mathrm{CV}$. The production of organic vegetables that $\mathrm{CV}$ has requested is of various kinds, starting from fruit, leaf, and flower vegetables produced by KWT partners who are members of the Mutiara Farm group.

The selling price of vegetables follows the policy between KWT Mutiara Farm and CV. KKAF. KWT Mutiara Farm is responsible for the marketing of vegetable farmers for its member partners. The price given to the farmer is the same as that paid by CV. KKAF to KWT Mutiara Farm. There is no difference in price because the KWT is only used as a container for the partner farmers' vegetables, where a portion of the sales profit goes into the KWT operating cash.

2. The partnership between CV. Kurnia Kitri Ayu Farm with a Baby Care Company

The baby porridge company (Baby Care) in the supply chain is a partner who buys organic vegetables directly from CV. KKAF. Baby Care is a home industry that produces organic baby porridge which all the main ingredients of vegetables are supplied from CV. KKAF. The partnership pattern formed in both of them is a sub-contract partnership, where there is an agreement that has been agreed upon between the two parties. The purchase of organic vegetables is adjusted to the amount discussed in the agreement and payment is made in cash (cash) which is paid every meeting of the two 
parties, namely every month. Baby Care does not sell its organic vegetables to other parties because vegetables will be used as the main raw material for the production of baby porridge. The delivery of organic vegetables to its branch outlets is handled by the company itself and CV KKAF is not involved. The role of a CV here is only as a supplier or distributor.

3. The partnership between CV. Kurnia Kitri Ayu Farm with a supermarket distributor

Distributors in the organic vegetable supply chain are parties with non-permanent partners, so the partnership pattern that is formed is a general trade partnership pattern. Supplies sent to distributors are not routine, such as deliveries to Baby Care. Distributors who work with CV. KKAF is the distributor for Surabaya and Kalimantan which will later market organic vegetables to supermarkets. Vegetable deliveries are scheduled for out-of-town distributors on Thursday, but within a month there are sometimes only two deliveries. The price given by Kurnia Kitri Ayu Farm to the distributor is Rp. $14,000 / \mathrm{kg}$, the distributor will later sell to supermarkets for 22,500.- / kg or Rp. 4,500, - / pcs (200grm).

Evaluation Analysis of Trust, Commitment, Communication, Satisfaction, and Dependence in Organic Vegetable Supply Chain Partnership Relationships

1. Trust Analysis

Trust is an attitude or pleasure in carrying out cooperation between two parties. A business will run well if its partner members trust each other, with this trust a commitment will be formed. According to Charu and Sameer (2000) supply chain performance is determined by the level of company trust in its suppliers and organizational flexibility. The results of the assessment of the trust variable obtained (a) The value of trust in the supplier's KWT to CV. Kurnia Kitri Ayu Farm has an average value of $80 \%$ which is included in the category of supplier of trust, (b) Trust value of CV. Kurnia Kitri Ayu Farm on KWT suppliers has an average value of $96 \%$ with the CV category. Kurnia Kitri Ayu Farm feels very confident, (c) The trust value of CV. Kurnia Kitri Ayu Farm for the baby porridge company (Baby Care) has a value of $100 \%$ in the CV category. Kurnia Kitri Ayu Farm feels very confident, (d) The trust value of the baby porridge company (Baby Care) in the CV. 92\% of Kurnia Kitri Ayu Farm is in the very trusting category.

Agricultural Socio-Economics Journal

\section{Commitment Analysis}

According to Amir et al (2014), commitment is an agreement between the two parties in a partnership relationship regarding the rules for carrying out cooperation. Commitment is also a desire to extend the cooperation relationship or maintain it, therefore commitment is important in establishing a cooperative relationship in the supply chain. Commitment comes from mutual trust. According to Stefani and Sunardi (2014), commitment and trust are the main factors that support company collaboration with suppliers. The results of the assessment of the commitment variable are obtained (a) The value of the supplier's KWT commitment to CV. Kurnia Kitri Ayu Farm has an average value of $71.67 \%$ including in the good category, (b) commitment value of CV. Kurnia Kitri Ayu Farm towards KWT suppliers has an average value of $91.67 \%$ which is included in the very good category, (c) The commitment value of CV. Kurnia Kitri Ayu Farm to $100 \%$ baby care company is included in the very good category, (d) The commitment value of the baby porridge company (Baby Care) to CV. 90\% of Kurnia Kitri Ayu Farm is in the very good category.

\section{Communication Analysis}

Communication can be said to be an important element in building a partnership. A relationship can run properly if always communicating regularly or continuously and communicating well. Fitri, Rahardjo, et al (2010) that communication has a higher effect on improving supply chain performance compared to commitment. Delivery of certain information can occur by communicating. The results of the communication variable analysis obtained (a) Assessment of supplier KWT communication to CV. Kurnia Kitri Ayu Farm has an average value of $80 \%$, including in the category of frequent communication, (b) Communication value of CV. Kurnia Kitri Ayu Farm towards KWT suppliers has an average value of $88.33 \%$ including in the very frequent category, (c) Communication value CV. Kurnia Kitri Ayu Farm to 100\% of the baby porridge company (Baby Care) is included in the very frequent category, (d) The communication value of the baby porridge company (Baby Care) to CV. $80 \%$ of Kurnia Kitri Ayu Farm is in the frequent category.

\section{Satisfaction Analysis}

Satisfaction is an attitude or emotion that arises as a result of something fun that can motivate someone to get output or work results in good 
quality and quantity according to the responsibilities they carry. Wibowo (2015) argues that satisfaction is a predictor of performance because satisfaction has a moderate correlation with performance, the level of satisfaction will affect performance. The results of the satisfaction score analysis show that (a) Evaluation of supplier KWT satisfaction with CV. Kurnia Kitri Ayu Farm has an average score of $68 \%$, including in the quite satisfied category, (b) The satisfaction score of CV. Kurnia Kitri Ayu Farm on KWT suppliers has an average value of $90.67 \%$, including in the very satisfied category, (c) Satisfaction value CV. Kurnia Kitri Ayu Farm for $100 \%$ of the baby porridge company (Baby Care) is included in the very satisfied category, (d) The satisfaction value of the baby porridge company (Baby Care) to CV. 92\% of Kurnia Kitri Ayu Farm is in the very satisfied category.

\section{Dependency Analysis}

Cooperation that is carried out based on trust and mutual communication will create commitment between the two parties. After all, aspects are fulfilled in a partnership, a sense of satisfaction and dependence will arise. According to Ferrer et al (2010), dependence is a prediction regarding the creation of a contractual relationship and cooperation between organizations. The results of the dependency value analysis show that (a) The assessment of the dependence of KWT suppliers on the CV. Kurnia Kitri Ayu Farm has an average value of $68.33 \%$ which is included in the fairly dependent category, (b) The value of CV dependency. Kurnia Kitri Ayu Farm on KWT suppliers has an average value of $95 \%$, including in the highly dependent category, (c) The value of CV dependence. Kurnia Kitri Ayu Farm for $100 \%$ of the baby care company is included in the highly dependent category, (d) The value of the dependence of the Baby Care Company on the CV. $90 \%$ of Kurnia Kitri Ayu Farm is in the highly dependent category

\section{CONCLUSION}

This research concludes that the flow of organic vegetable products moves from partner farmers to KWT and flows to Kurnia Kitri Ayu Farm, then flows to Baby Care and distributors. The direction of the financial flow is inversely related to the flow of the product. The flow of moving information from company partners that flows to CV. Kurnia Kitri Ayu then moved to suppliers and vice versa. The partnership patterns formed in this study are the plasma core pattern (between CV. KKAF and KWT
Mutiara Farm), sub-contract patterns (between CV. KKAF and Baby Care Companies), and general trading patterns (between CV. KKAF and distributors). Assessment of the organic vegetable supply chain partnership relationship (a) The relationship of supplier KWT to the performance of CV. Kurnia Kitri Ayu Farm resulted that the average KWT felt confident (80\%), committed well $(71.67 \%)$, communicated frequently $(80 \%)$, and was quite satisfied (68\%), and felt dependent $(68,33 \%)$ on the performance of CV. Kurnia Kitri Ayu Farm, (b) Assessment of CV. Kurnia Kitri Ayu Farm on the performance of KWT shows that the average result of $\mathrm{CV}$ Kurnia Kitri feels very confident (96\%), very good commitment (91.67\%), very frequent communication $(88.33 \%)$, feels very satisfied (90.67\%), and highly dependent (95\%) on the supplier's KWT performance, (c) Assessment of CV. Kurnia Kitri Ayu Farm regarding its relationship with Baby Care obtained the results of CV. Kurnia Kitri feels very confident (100\%), makes commitments very well (95\%), communicates very often $(100 \%)$, feels very satisfied $(100 \%)$, and highly dependent $(100 \%)$ on the performance of Baby Care, and ( d) Baby Care assessment regarding its relationship with $\mathrm{CV}$. Kurnia Kitri Ayu Farm shows that Baby Care feels very confident $(92 \%)$, has a very good commitment (90\%), communicates frequently (80\%), feels very satisfied (92\%), and is very dependent (90\%) on performance CV. Kurnia Kitri Ayu Farm

\section{REFERENCES}

Amir, N. O., Syafrial, \& Koestiono, D. (2014). Analisis Manajemen Rantai Pasokan (Supply Chain Management) Komoditas Pisang Mas Kirana (Kasus Pada Asosiasi Petani Pisang Mas Sridonoretno, Kec. Dampit, Kab. Malang). Habitat, $X X V(1)$.

Based on Indonesian Organic Agriculture Statistics Data. (2016). Indonesia Organic Alliance. Retrieved from https://goo.gl/Vigb5K

Charu, C., \& Sameer, K. (2000). Supply chain management in theory and practice:a passing fad or a fundamental change? Industrial Management \& Data Systems, 100(3), 100114. https://doi.org/10.1108/02635570010286168

Erfit. (2012). Analisis Kesetaraan dalam Kemitraan pada Agribisnis Hortikultura. Jurnal Embrio, 2(5), 132-143.

Ferrer, M., Santa, R., Hyland, P. W., \& Bretherthon, P. (2010). Relational factor that explain supply chain relationships. Asia Pacific 
Journal of Marketing and Logistics, 22,(3), $419-440$.

Fitri, M. N., Rahardjo, S. T., \& Kusumawardhani, A. (2010). Analisis Pengaruh Komitmen, Komunikasi dan strategi Kerjasama Jangka Panjang Pemasok dengan Perusahaan terhadap Kinerja Rantai Pasokan (Studi Empirik pada Pemasok Bahan Baku di PT. Charoen Pokphand Semarang), 1-17.

Larasati, N. L. M. B., \& Sursura, K. B. (2020). Pola Kemitraan antara Taman Ayu Agrowisata dengan Petani Kopi Luwak. Jurnl Agribisnis Dan Agrowisata, 9(2), 155-163.

Mayrowani, H. (2012). Pengembangan Pertanian Organik di Indonesia. Forum Penelitian Agro Ekonomi, 30(2), 91-108.

Muljaningsih, S. (2011). Preferensi Konsumen dan Produsen Produk Organik di Indonesia. Jurnal Sosial Dan Humaniora, 14(4), 1-5.
Nugroho, A. (2005). Strategi Jitu Memilih Metode Statistic Penelitian dengan SPSS. Yogyakarta: Andi Yogyakarta.

Poerwanto, R., \& Susila, A. D. (2014). Teknologi Hortikultura (1st ed.). Bogor: IPB Press.

Stefani, V., \& Sunardi, O. (2014). Peran Dependency, Commitment, Trust dan Communication terhadap Kolaborasi Rantai Pasok dan Kinerja Perusahaan: Studi Pendahuluan, 13(3).

Wibowo. (2015). Perilaku Dalam Organisasi. Jakarta: Rajawali Pers.

Yulianjaya, F., \& Hidayat, K. (2016). Pola Kemitraan Petani Cabai Dengan Juragan Luar Desa (Studi Kasus Kemitraan di Desa Kucur, Kecamatan Dau, Kabupaten Malang). Jurnal Habitat, 27(1), 37-47. https://doi.org/10.21776/ub.habitat.2016.027. 1.5 